\title{
Relationship of Age and Different Histological Types of Ovarian Tumors
}

\author{
SHAHNAZ BEGUM ${ }^{1}$, FERDOUSI BEGUM ${ }^{2}$, NASIMUL GANI ${ }^{3}$, \\ FARHANARAHMAN ${ }^{4}$, FARHANAISRAT JAHAN ${ }^{5}$,
}

\begin{abstract}
Background: Ovarian tumours are common problem in gynaecology and have varied age of appearance of different histopathological types.

Objective: This study was undertaken to find out the relationship of age and different histological types of ovarian tumors

Methods: A retrospective study was carried out in the Department of Obstetrics and Gynaecology and Department of Pathology, Sir Salimullah Medical College and Mitford Hospital, Dhaka, during May 2010 and December 2014. Five hundred forty seven (547) cases of ovarian tumours were studied in respect to their age and histopathological appearance.

Results: The range of age of patients with ovarian tumour was $11-82$ years. About $63 \%$ malignant and $73 \%$ benign ovarian tumours were found in the age group of $20-49 \mathrm{yrs}$. About $31 \%$ malignant ovarian tumours and $15 \%$ Benign tumours occurred in menopausal woman ( $\leq 50$ yrs.). Overall, mean age of presentation of ovarian tumours was $34.29 \pm 12.84$ yrs. Mean age of patients with malignant ovarian tumour was $40.29 \pm 14.28$ (median 40 yrs; mode 45 yrs.). Mean age of benign ovarian tumour was $34.69 \pm 13.08$ (median 34 yrs; mode 40yrs) and mean age for borderline tumours $32.75 \pm 11.70 \mathrm{~mm}$ (median $33 \mathrm{yrs}$, mode 20 yrs.). Mean age of non tumour ovarian masses / cysts was $31.14 \pm 10.76$ yrs (median 29.5; mode 25.4). The difference of mean age of occurance of malignant and benign ovarian tumours were statistically significant $P<0.00>$. Dysgerminoma (mean age $23.5 \pm 4.43$ ) and yolk sac tumour (mean age $18.00 \pm 5.00 \mathrm{yrs}$ ) occurred in younger patients. Serous cyst adenocarcinoma, endometriod carcinoma and poorly differentiated carcinoma occurred around 45 years of age. Mean age of presentation of most of the benign ovarian tumours was between $30-37$ yrs.; except thecoma which occurred in extremes of age.

Conclusion: Most of the patients with malignant and benign ovarian tumours have presented in reproductive age adult women (20 - 49 yrs.); and some specific varieties of tumour (e.g. thecoma) presented in the extremes of age.
\end{abstract}

Key word: ovarian tumour; age and ovarian tumour, benign ovarian tumour, malignant ovarian tumour, borderline ovarian tumour.

Introduction:

Ovarian tumours are one of the major health problems confronting the general practitioners in general and gynaecologists in particular. Ovarian tumours may either be asymptomatic, found on the routine ultrasound examination or symptoms may be vague

1. Assistant Professor, Department of Obstetrics and Gynaecology, Sir Salimullah Medical College and Mitford Hospital, Dhaka

2. Professor, Department of Obstetrics and Gynaecology, Sir Salimullah Medical College and Mitford Hospital, Dhaka,

3. Professor, Department of Patholgy, Sir Salimullah Medical College, Dhaka,

4. Registrar Department of Obstetrics and Gynaecology, Sir Salimullah Medical College and Mitford Hospital, Dhaka

5. Assistant registrar, Department of Obstetrics and Gynaecology, Sir Salimullah Medical College and Mitford Hospital, Dhaka,

Address of Correspondence: Dr. Shahnaz Begum, Assistant Professor, Department of Obstetrics and Gynaecology, Sir Salimullah Medical College and Mitford Hospital, Dhaka, Phone: 01718761353 Email: dr.shahnaz@yahoo.com 
till the patient has an acute emergency like torsion or rupture of a benign cyst. The worst is late presentation of a malignant ovarian tumour. Ovarian cancer accounts for $3 \%$ of all cancers in women; $80 \%$ of the ovarian tumors are benign, occurring in the age group of 20 to 45 years whereas malignant tumors are common in elderly women, between 45 to 65 years. ${ }^{1}$ Exact incidence in Bangladesh is not known but ovarian cancer is the sixth most common cancer among females of Bangladesh; fourth most common cause of death due to genital malignancies including breast. and continues to present at an advanced stage.[2] Incidence of ovarian malignancy is 4.7\%; 5-year prevalence rate is $5.1 \%$ (7625 cases) and mortality rate is $5.1 \% .^{2}$ Estimated incidence, mortality and 5year prevalence for women in south eastern Asia is $4.9 \%, 5 \%$ and $4.4 \%$ respectively; which is $3.6 \%$, $4.3 \%$ and $3.4 \%$ for the world women population, respectively. [2] Benign ovarian cysts may occur at any point in the life but they are most common during childbearing age and constitute about $90 \%$ of ovarian tumours. Most benign tumours are cystic and finding of solid elements make malignancy more likely. In most of the population based cancer registries in India, ovarian cancer is the third leading site of cancer among women trailing behind cervix and breast cancer. The age adjusted incidence rates of ovarian cancer vary between 5.4 and 8 ( $7.8 \%$ in Kolkata) per 100,000 populations in different parts of the country. $^{3}$

The present study was undertaken to find out the relationship of age and different histological types of ovarian tumors

\section{Methodology:}

This retrospective study included 547 histopathologically proven ovarian tumour cases, during May 2010 and December 2014, admitted to Department of Obstetrics and Gynaecology, Sir Salimullah Medical College and Mitford Hospital (SSMCH), Dhaka. Out of 613 suspected ovarian tumour cases, histopathology was done on 547 $(89.2 \%)$ cases in the Department of Pathology, $\mathrm{SSMCH}$, rest were done in other pathology centres. Patients with pelvic or abdomino-pelvic masses supported by clinical findings and ultra-sonogram presenting as primary ovarian masses were included in this study. Age of all the patients were obtained from records. Tissue for histopathology was sent to the laboratory in formalin solution and was prepared under standard condition for paraffin embedding. The sections were stained with haematoxilin and eosin $(\mathrm{H}$ $\& E)$. The histological classification of ovarian tumour by WHO was used.[4] Ethical clearance was obtained from the institutional ethical committee. Confidentiality was strictly maintained.

\section{Results:}

Among 539 cases diagnosed as ovarian tumour, 55 $(10.2 \%)$ were in $11-19$ yrs age category; $405(75.1 \%)$ were in 20-40 yrs age group; and 79 (14.7\%) occurs in postmenopausal age group (50-75 yrs). Among the patients with malignant ovarian tumour, $(\mathrm{N}=38)$ : majority $(24,63-2 \%)$ occurred in $20-49$ yrs age group, followed by 11 (28.9\%) among 50-69 age group, 2(5.3\%) among 11-19 yrs age group and $1(2.6 \%)$ among $\geq 70$ yrs age group (table 1$)$. Regarding benign ovarian tumours $(n=379)$; majority $(278,73.4 \%)$ occurred in 20-49 yrs age group; 53 (13.7\%) occurred in 50-69 yrs age group; 43 (11.3\%) occurred in teenagers (11-19 yrs age group). Four cases of borderline ovarian tumours were found in 20-49 yrs age group. Among ovarian tumours categorized as "others" $(n=118)$ : most of the cases 99 (83.9\%) were in $20-40 \%$ age group; $10(85 \%)$ occurred in teen agers ; 8 (6.8\%) occurred in $50-69$ yrs age group \& only one case $1(0.8 \%)$ occurred in women $\leq 70 \mathrm{yrs}$ of age. There was no significant difference of occurrence of various types of ovarian tumours on different age groups. $(p=0.053)$ (Table I).

Table II shows the mean age of occurrence of different types of ovarian tumours. Mean age of patients with malignant ovarian tumours was $40.29 \pm 14.28 \mathrm{yrs}$ (median $40 \mathrm{yrs}$; mode $45 \mathrm{yrs}$ ). Mean age of presentation of benign ovarian tumours was $34.69 \pm$ 13 yrs (median 34 yrs; mode 40 yrs). The difference of age of occurrence of malignant and benign ovarian tumours were statistically significant $(p<0.01)$. Mean age of occurrence of border line ovarian tumours was $32.75 \pm 11.7$, (median 33, mode $20 \mathrm{yrs}$ ). In "others" group of tumour which includes hemorrhagic cyst, chocolate cyst and twisted ovarian cysts, mean age was $31.14 \pm 1076 \mathrm{yrs}$; (median $29.5 \mathrm{yrs}$ and mode was $25 \mathrm{yrs}$ ). Difference of age was statistically significant between malignant tumours and others $(P>$ .001) and between benign tumours and others (Table-II).

The mean age of patients with serous cyst adenocarcinoma (n 21) was $44.24 \pm 13.33$ yrs ; 
Table-I

Distribution of histopathological types of ovarian tumour by age of the patients $(n=539)$

\begin{tabular}{lccccc}
\hline Age (years) & $\begin{array}{c}\text { Malignant } \\
(\mathrm{n}=38)\end{array}$ & $\begin{array}{c}\text { Benign } \\
(\mathrm{n}=379)\end{array}$ & $\begin{array}{c}\text { Borderline } \\
(\mathrm{n}=4)\end{array}$ & $\begin{array}{c}\text { Others } \\
(\mathrm{n}=118)\end{array}$ & $\begin{array}{c}\text { Total } \\
(\mathrm{n}=539)\end{array}$ \\
& No. $(\%)$ & No. $(\%)$ & No. $(\%)$ & No. $(\%)$ & No. $(\%)$ \\
\hline $11-19$ & $2(5.3)$ & $43(11.3)$ & 0 & $10(8.5)$ & $55(10.2)$ \\
$20-49$ & $24(63.2)$ & $278(73.4)$ & $4(100.0)$ & $99(83.9)$ & $405(75.1)$ \\
$50-69$ & $11(28.9)$ & $52(13.7)$ & 0 & $8(6.8)$ & $71(13.2)$ \\
$\geq 70$ & $1(2.6)$ & $6(1.6)$ & 0 & $1(0.8)$ & $8(1.5)$ \\
\hline
\end{tabular}

Chi square test, $\mathrm{P}=0.053$ (not significant)

Table-II

Mean age of patients of different types of ovarian tumour

\begin{tabular}{|c|c|c|c|c|c|}
\hline \multirow[b]{2}{*}{ Tumour type } & \multicolumn{5}{|c|}{ Age (years) } \\
\hline & $\mathrm{n}$ & Range & Mean $\pm S D$ & Median & Mode \\
\hline Malignant & 38 & 1470 & $40.29 \pm 14.28$ & 40.00 & 45.00 \\
\hline Benign & 379 & 1182 & $34.69 \pm 13.08$ & 34.00 & 40.00 \\
\hline Borderline & 4 & 2045 & $32.75 \pm 11.70$ & 33.00 & 20.00 \\
\hline Others & 118 & 1375 & $31.14 \pm 10.76$ & 29.50 & 25.00 \\
\hline Total & 539 & 1182 & $34.29 \pm 12.84$ & 32.00 & 40.00 \\
\hline \multicolumn{3}{|c|}{ Comparison of age between types of tumour } & \multicolumn{2}{|c|}{ Pvalue } & \\
\hline \multicolumn{3}{|c|}{ Malignant vs Benign } & \multicolumn{2}{|c|}{$0.010^{* *}$} & \\
\hline \multicolumn{3}{|c|}{ Malignant vs Borderline } & \multicolumn{2}{|c|}{$0.259^{\text {ns }}$} & \\
\hline \multicolumn{3}{|c|}{ Malignant vs Others } & \multicolumn{2}{|c|}{$0.0001^{* * *}$} & \\
\hline \multicolumn{3}{|c|}{ Benign vs Borderline } & \multicolumn{2}{|c|}{$0.761^{\mathrm{ns}}$} & \\
\hline \multicolumn{3}{|c|}{ Benign vs Others } & \multicolumn{2}{|c|}{$0.008^{* *}$} & \\
\hline \multicolumn{3}{|c|}{ Borderline vs Others } & \multicolumn{2}{|c|}{$0.802^{\text {ns }}$} & \\
\hline
\end{tabular}

ANOVA (Post Hoc), ns $=$ Not significant, ${ }^{* *}=P<0.01,{ }^{* * *}=P<0.001$

Range of age of patients with ovarian tumour was $11-82$ years.

median 45 yrs and mode 50. In mucinous cyst adenocarcinoma patients ( $n=7)$, mean age was 40.57 \pm 14.0, (median 35 and mode was $35 \mathrm{yr}$ ). Mean age of dysgerminoma $(n=4)$, endometroid tumours $(n=2)$, yolk sac tumours, was $23.5 \pm 4.43 ; 44 \pm 141$ and $18 \pm 5.60$ years respectively. In transitional cell carcinoma $(n=1)$ and poorly differential carcinoma $(n=1)$ mean age was 55 and 45 yrs respectively (Table-III).

Table IV shows the range, mean (average age), median (the age of the women in the middle of the range) and mode (common age of occurrence i.e. most of the tumour found in this age) age of different benign and borderline ovarian tumours. Because of wide range of age of occurrence of most of the types of ovarian tumour mean age varied from the mode i.e. common age of occurrence of that kind of tumour.
In serous cyst adenoma, the most common type ovarian tumour, though mean age was $34.12 \pm 14.07$ years but it commonly found in women of 30 years of age (mode $30 \mathrm{yrs}$.). Findings are similar in mucinous cyst adenoma, thecoma and borderline mucinous tumour. On the other hand, there are some tumours where mean age is less than (Table -4$)$ that the age of common occurrence e.g. simple cysts, follicular cyst and ovarian fibroid.

Table $V$ shows specific age range of occurrence of malignant ovarian tumours. Though most cases occurred in 35 - $54 \mathrm{yrs}$; but it started from $20 \mathrm{yrs}$ and extended upto 70 yrs., whereas dysgerminoma and yolk sac tumour occurred in much younger age.

Table VI and VII shows different age range of patients presented with different benign and borderline ovarian tumours. Serous and mature cystic teratoma started 
Table-III

Age of patients of different types of malignant ovarian tumour $(n=38)$

\begin{tabular}{lccccc}
\hline & \multicolumn{5}{c}{ Age (years) } \\
\cline { 2 - 6 } Tumour type & $\mathrm{n}$ & Range & Mean \pm SD & Median & Mode \\
\hline Serous cyst adenocarcinoma & 21 & 2270 & $44.24 \pm 13.33$ & 45.00 & 50.00 \\
Mucinous cyst and papillary mucinous & 7 & 2562 & $40.57 \pm 14.00$ & 35.00 & 35.00 \\
cyst adenocarcinoma & & & & & \\
Dysgerminoma & 4 & 1828 & $23.50 \pm 4.43$ & 24.00 & 18.00 \\
Endometroid & 2 & 4345 & $44.00 \pm 1.41$ & 44.00 & 43.00 \\
Yolk sac tumour & 2 & 1422 & $18.00 \pm 5.66$ & 18.00 & 14.00 \\
Transitional cell carcinoma & 1 & 55 & 55.00 & 55.00 & 55.00 \\
Poorly differentiated carcinoma & 1 & 45 & 45 & 45.00 & 45.00 \\
\hline Total & 38 & $14-70$ & $40.29 \pm 14.28$ & 40.00 & 45.00 \\
\hline
\end{tabular}

Table-IV

Age of patients of different types of benign and borderline ovarian tumour ( $n=383)$

\begin{tabular}{lccccc}
\hline & \multicolumn{5}{c}{ Age (years) } \\
\cline { 2 - 6 } Tumour type & $\mathrm{n}$ & Range & Mean \pm SD & Median & Mode \\
\hline Serous cyst adenoma & 115 & 1170 & $34.12 \pm 14.07$ & 30.00 & 30.00 \\
Mature cyst teratoma & 76 & 1270 & $30.43 \pm 12.03$ & 29.50 & 30.00 \\
Mucinous cyst adenoma & 66 & 1382 & $37.86 \pm 14.81$ & 35.00 & 30.00 \\
Simple cyst & 46 & 1660 & $36.33 \pm 11.43$ & 35.00 & 40.00 \\
Follicular cyst & 42 & 1155 & $37.02 \pm 9.63$ & 40.00 & 40.00 \\
Corpus luteal cyst & 25 & 1650 & $31.76 \pm 8.75$ & 30.00 & 30.00 \\
Thecoma & 5 & 1870 & $48.60 \pm 19.62$ & 50.00 & 18.00 \\
Ovarian fibroid & 4 & $28-45$ & $37.00 \pm 9.27$ & 37.50 & 45.00 \\
Borderline mucinous tumouryyyy & 4 & 2045 & $32.75 \pm 11.70$ & 33.00 & 20.00 \\
Others: & & & & & \\
Haemorrhagic cyst & 81 & 1375 & $30.99 \pm 11.27$ & 28.00 & 25.00 \\
Chocolate cyst & 21 & 1850 & $32.62 \pm 7.92$ & 32.00 & 40.00 \\
Twisted ovary & 16 & 1360 & $29.94 \pm 11.71$ & 29.00 & 25.00 \\
\hline
\end{tabular}

Table-V

Types of malignant ovarian tumours according to age of the patients ( $n=38)$

\begin{tabular}{|c|c|c|c|c|c|c|c|c|c|c|c|c|c|}
\hline \multirow[t]{2}{*}{$\begin{array}{l}\text { Age group } \\
\text { (year) }\end{array}$} & \multicolumn{2}{|c|}{$\begin{array}{l}\text { Serous cyst } \\
\text { adeno- } \\
\text { carcinoma } \\
(n=21)\end{array}$} & \multicolumn{2}{|c|}{$\begin{array}{l}\text { Mucinous cyst } \\
\text { and papillary } \\
\text { mucinous cyst } \\
\text { adenocarcinoma } \\
(\mathrm{n}=7)\end{array}$} & \multicolumn{2}{|c|}{$\begin{array}{l}\text { Dysgerminoma } \\
(n=4)\end{array}$} & \multicolumn{2}{|c|}{$\begin{array}{l}\text { Endometroid } \\
\qquad(n=2)\end{array}$} & \multicolumn{2}{|c|}{$\begin{array}{l}\text { Yolk Tumour } \\
(n=2)\end{array}$} & \multicolumn{2}{|c|}{$\begin{array}{c}\text { Transitional } \\
\text { cell carcinoma } \\
(n=1) \\
\end{array}$} & \multirow{2}{*}{$\begin{array}{c}\text { Poorly } \\
\text { Differentiated } \\
\text { Carcinoma } \\
(n=1) \\
\end{array}$} \\
\hline & No. & $(\%)$ & No. & $(\%)$ & No. & $(\%)$ & No. & $(\%)$ & No. & $(\%)$ & No. & $(\%)$ & \\
\hline 1114 & 0 & & 0 & & 0 & & 0 & & 1 & $(50.0)$ & 0 & & 0 \\
\hline 1519 & 0 & & 0 & & 1 & $(25.0)$ & 0 & & 0 & & 0 & & 0 \\
\hline 2024 & 1 & $(4.8)$ & 0 & & 1 & $(25.0)$ & 0 & & 1 & $(50.0)$ & 0 & & 0 \\
\hline $25-29$ & 2 & $(9.5)$ & 2 & $(28.6)$ & 2 & $(50.0)$ & 0 & & 0 & & 0 & & 0 \\
\hline $30-34$ & 1 & $(4.8)$ & 0 & & 0 & & 0 & & 0 & & 0 & & 0 \\
\hline $35-39$ & 3 & $(14.3)$ & 2 & $(28.6)$ & 0 & & 0 & & 0 & & 0 & & 0 \\
\hline $40-44$ & 3 & $(14.3)$ & 0 & & 0 & & 1 & $(50.0)$ & 0 & & 0 & & 0 \\
\hline 4549 & 2 & $(9.5)$ & 1 & (14.3) & 0 & & 1 & $(50.0)$ & 0 & & 0 & & $1(100.0)$ \\
\hline 5054 & 4 & $(19.0)$ & 0 & & 0 & & 0 & & 0 & & 0 & & 0 \\
\hline 5559 & 1 & $(4.8)$ & 1 & (14.3) & 0 & & 0 & & 0 & & 1 & $(100.0)$ & 0 \\
\hline 6064 & 2 & $(9.5)$ & 1 & (14.3) & 0 & & 0 & & 0 & & 0 & & 0 \\
\hline 6569 & 1 & $(4.8)$ & 0 & 0 & 0 & 0 & 0 & 0 & & & & & \\
\hline$\geq 70$ & 1 & $(4.8)$ & 0 & & 0 & & 0 & & 0 & & 0 & & 0 \\
\hline
\end{tabular}


Table-VI

Types of benign ovarian tumours according to age of the patients $(n=379)$

\begin{tabular}{|c|c|c|c|c|c|c|c|c|c|c|c|c|c|c|c|c|}
\hline \multirow[t]{2}{*}{$\begin{array}{l}\text { Age group } \\
\text { (year) }\end{array}$} & \multicolumn{2}{|c|}{$\begin{array}{c}\text { Serous cyst } \\
\text { Adenoma } \\
(n=115)\end{array}$} & \multicolumn{2}{|c|}{$\begin{array}{c}\text { Mature cystic } \\
\text { teratoma } \\
(\mathrm{n}=76) \\
\end{array}$} & \multicolumn{2}{|c|}{$\begin{array}{c}\text { Mucinous } \\
\text { cyst adenoma } \\
(\mathrm{n}=66) \\
\end{array}$} & \multicolumn{2}{|c|}{$\begin{array}{l}\text { Simple cyst } \\
(n=46)\end{array}$} & \multicolumn{2}{|c|}{$\begin{array}{l}\text { Follicular cyst } \\
\quad(n=42)\end{array}$} & \multicolumn{2}{|c|}{$\begin{array}{c}\text { Corpus luteal } \\
\text { cyst } \\
(n=25) \\
\end{array}$} & \multicolumn{2}{|c|}{$\begin{array}{c}\text { Thecoma } \\
(n=5)\end{array}$} & \multicolumn{2}{|c|}{$\begin{array}{c}\text { Ovarian } \\
\text { fibroid } \\
(n=4)\end{array}$} \\
\hline & No. & $(\%)$ & No. & $(\%)$ & No. & $(\%)$ & No. & $(\%)$ & No. & $(\%)$ & No. & $(\%)$ & No. & $(\%)$ & No. & $\%$ \\
\hline $11-14$ & 4 & (3.5) & 6 & (7.9) & 1 & (1.5) & 0 & & 1 & $(2.4)$ & 0 & & 0 & & 0 & \\
\hline $15-19$ & 13 & $(11.3)$ & 8 & (10.5) & 3 & $(4.5)$ & 3 & $(6.5)$ & 1 & $(2.4)$ & 2 & (8.0) & 1 & $(20.0)$ & 0 & \\
\hline $20-24$ & 20 & (17.4) & 7 & $(9.2)$ & 10 & (15.2) & 5 & (10.9 & 3 & $(7.1)$ & 2 & $(8.0)$ & 0 & & 0 & \\
\hline $25-29$ & 8 & $(7.0)$ & 17 & $(22.4)$ & 7 & $(10.6)$ & 6 & (13.0) & 3 & $(7.1)$ & 6 & $(24.0)$ & 0 & 1 & $(25.0)$ & \\
\hline $30-34$ & 18 & (15.7) & 10 & (13.2) & 8 & (12.1) & 3 & $(6.5)$ & 4 & (9.5) & 8 & $(32.0)$ & 0 & 1 & $(25.0)$ & \\
\hline $35-39$ & 9 & $(7.8)$ & 12 & (15.8) & 8 & (12.1) & 7 & (15.2) & 7 & (16.7) & 0 & 0 & 0 & & & \\
\hline $40-44$ & 15 & $(13.0)$ & 8 & (10.5) & 8 & (12.1) & 10 & (21.7) & 13 & $(31.0)$ & 4 & $(16.0)$ & 0 & 0 & & \\
\hline $45-49$ & 5 & (94.3) & 3 & $(3.9)$ & 5 & $(7.6)$ & 5 & (10.9) & 7 & (16.7) & 2 & $(8.0)$ & 1 & $(20.0)$ & 2 & $(50.0)$ \\
\hline $50-54$ & 10 & (8.7) & 1 & (1.3) & 7 & (10.6) & 3 & (6.5) & 2 & $(4.8) 1$ & & & (20.0) & 0 & & \\
\hline $55-59$ & 4 & $(3.5)$ & 0 & 2 & (3.0) & 2 & (4.3) & 1 & (2.4) & & 0 & & 0 & & 0 & \\
\hline $60-64$ & 6 & $(5.2)$ & 2 & $(2.6)$ & 3 & (4.5) & 2 & $(4.3)$ & 0 & & 0 & & 1 & $(20.0)$ & 0 & \\
\hline $65-69$ & 2 & (1.7) & 1 & (1.3) & 1 & $(1.5)$ & 0 & & 0 & & 0 & & 0 & & 0 & \\
\hline$\geq 70$ & 1 & $(0.9)$ & 1 & (1.3) & 3 & $(4.5)$ & 0 & & 0 & & 0 & & 1 & $(20.0)$ & 0 & \\
\hline
\end{tabular}

Table-VII

Types of borderline and miscellaneous ovarian tumours according to age of the patients $(n=122)$

\begin{tabular}{|c|c|c|c|c|c|c|c|c|}
\hline & \multicolumn{2}{|c|}{$\begin{array}{l}\text { Borderlinemucinous } \\
\text { tumour }(n=4)\end{array}$} & \multicolumn{2}{|c|}{$\begin{array}{l}\text { Haemmorhagiccyst } \\
(n=81)\end{array}$} & \multicolumn{2}{|c|}{$\begin{array}{l}\text { Chocolate cyst } \\
(n=21)\end{array}$} & \multicolumn{2}{|c|}{$\begin{array}{l}\text { Twisted ovary } \\
(n=16)\end{array}$} \\
\hline & No. & $\%$ & No. & $\%$ & No. & $\%$ & No. & $\%$ \\
\hline $11-14$ & 0 & & & $3(3.7)$ & 0 & & 2 & (12.5) \\
\hline $15-19$ & 0 & & 4 & $(4.9)$ & 1 & (4.8) & 0 & \\
\hline $20-24$ & 1 & $(25.0)$ & 15 & (18.5) & 1 & (4.8) & 2 & (12.5) \\
\hline $25-29$ & 1 & (25.0) & 21 & (25.9) & 6 & (28.6) & 4 & (25.0) \\
\hline $30-34$ & 0 & & 11 & (13.6) & 5 & (23.8) & 5 & (31.3) \\
\hline $35-39$ & 0 & & 7 & $(8.6)$ & 2 & $(9.5)$ & 1 & (6.3) \\
\hline $40-44$ & 1 & $(25.0)$ & 7 & (8.6) & 4 & $(19.0)$ & 0 & \\
\hline $45-49$ & 1 & $(25.0)$ & 7 & (8.6) & 1 & $(4.8)$ & 0 & \\
\hline $50-54$ & 0 & & 4 & (4.9) & 1 & (4.8) & 1 & (6.3) \\
\hline $55-59$ & 0 & & 0 & & 0 & & 0 & \\
\hline $60-64$ & 0 & & 1 & (1.2) & 0 & & 1 & (6.3) \\
\hline 65-69 & 0 & & 0 & & 0 & & 0 & \\
\hline$\geq 70$ & 0 & & 1 & (1.2) & 0 & & 0 & \\
\hline
\end{tabular}

occurring from 11 years, most of them presented around 11-54 yrs \& then decreased ; where as in mucinous cyst adenoma, simple cyst, chocolate cyst started occurring a later age i.e. after $20 \mathrm{yrs}$ of age and mostly occured upto 60 and 65 years.

\section{Discussion:}

Age of occurrence of ovarian tumour as a whole and different histopathological types vary. Ethnicity, geographical region and many other factors may influence it. Malignant ovarian tumors are more common above 40 years. ${ }^{5}$ Nayak, in lindia, has shown that among the benign tumours $42(44.2 \%)$ were seen in patients between 31 and 40 years of age followed by $26(27.4 \%)$ which were seen in the 21 to 30 age group. The youngest patient in their study was 13 years old while the oldest was 70 years old. Therefore the $20-40$ year age group comprised $71.6 \%$ of all patients with ovarian tumours in their study. ${ }^{6}$ lyoke in Nigeria studied 54 cases of primary ovarian cancer: epithelial ovarian cancer constituted $68 \%$ of cases of ovarian cancer $(95 \% \mathrm{Cl} 54 \%, 82 \%)$ : Sex cord and germ cell tumors constituted $16 \%$ each (95\% Cl 6\%, 26\%). Approximately $60 \%$ of women who had epithelial ovarian cancer were aged 50 years or below $(95 \% \mathrm{Cl} 47 \%, 74 \%) .{ }^{7}$ In a study in Iran, there were 152 cases of ovarian cancer, $102(67.1 \%)$ epithelial type, 26 (17.1\%) germ cell tumors, 14 $(9.2 \%)$ sex cord stromal and $10(6.6 \%)$ metastatic ovarian tumors. Epithelial type tumors and sex cordstromal tumors were more prevalent after the age 50 ( 40 and $44.4 \%$ consequently). Germ cell tumors were more prevalent before 20 (16 cases, $61.5 \%)($ chi2 $=$ 42.54, p-value $=0.000) .{ }^{8}$

Among Malaysians, majority (78\%) of the benign tumours occurred between the age of 20-49 years. The peak incidence was in the 3rd decade. For 
epithelial tumours alone, $93 \%$ occurred between the ages of $20-59 \%$ years. Mucinous tumours seem to occur equally at all ages from $10-59$ years. Mucinous tumours and teratomas have the widest range of age distribution. ${ }^{9}$

In a small case series mean ( $\pm S D$ ) age of 28 patients of histopathological confirmed ovarian cancer of Bangladesh was $40.6( \pm 12.5)$ years (Range 13 to 63 years). ${ }^{10}$

A review was undertaken on 1648 cases of histopathologically diagnosed ovarian tumors and tumor-like lesions, and information on the age of the patients and size of the tumor were obtained. There were $840(51 \%)$ cases of benign tumors, $73(4 \%)$ cases of tumors of low malignant potential (LMP), $268(16 \%)$ cases of malignant tumors and $467(28 \%)$ cases of tumor-like lesions. The age of the patients was significantly different among tumor-like lesions (34.6+/-8.1 years), benign tumors $(39.8+/-16.4$ years), low malignant potential (LMP) tumors (45.2+/ -18.3 years) and malignant tumors $(51.9+/-13.0$ years) $(P<0.0001)$. [11] Jha and Karki in a study on 161 ovarian tumors in Tribhuvan University Teaching Hospital, Nepal found that two third of ovarian tumors occur in women of reproductive age group. Most ovarian tumors (47.2\%) were seen between $21-40$ years whereas most malignant tumors $(73.1 \%)$ were seen above 40 years. In 1 st two decades, germ cell tumors were more common than other tumors. ${ }^{12}$

In the book "WHO classification of Tumours in Female" Kumar RJ et al have mentioned age of the patients with different kinds of ovarian tumours according to the new WHO classification system. ${ }^{13}$

In serous cystadenoma, adenofibroma and surface papilloma patients age ranged from 40 to 60 years; in serous borderline tumour /atypical proliferative serous tumour, the mean age of patients is 42 years; and in serous borderline tumour - micropapillary variant / non-invasive low-grade serous carcinoma : mean age of patients is 45 years. In mucinous cystadenoma / adenofibroma mean age is 50 years. In mucinous borderline tumour / atypical proliferative mucinous tumour: the tumours occur across a wide age range from 13-88 years, with a mean age of 40-49 years. In mucinous carcinoma: mean age at presentation is 45 years. ${ }^{13}$
Endometrioid tumours \& endometriotic cyst are among the most common causes of ovarian enlargement in the fourth and fifth decades. In endometrioid cystadenoma /adenofibroma, the average age of patients is 55 years : In endometrioid borderline tumour/ atypical proliferative endometrioid tumour average age of patients is 51 years. Endometrioid carcinoma is most common in the fifth and sixth decades of life. ${ }^{13}$

Clear cell tumours: Regarding clear cell cystadenoma I adenofibroma, clear cell borderline tumour, atypical proliferative clear cell tumour almost all the women are postmeno pausal (mean age, 59-68 years). In clear cell carcinoma mean age is 55 years.

Brenner tumours : majority of these tumours arise in adults in the fifth to seventh decades, although they may occur in patients younger than thirty or older than eighty years. In borderline Brenner tumour / atypical proliferative Brenner tumour: mean patient age is 59 years. Malignant Brenner tumours occur in women over 50 years of age. ${ }^{13}$

Seromucinous tumours is a benign cystic neoplasm with two or more Mullerian cell types, all accounting for at least $10 \%$ of the epithelial. Rare tumours have more prominent fibrous stroma (adenofibroma). The average age of patients is $34-44$ years. In seromucinous carcinoma mean age in one reported series was 45 years. In undifferentiated carcinoma patients are diagnosed at a mean age of 55 years. About mesenchymal tumours less than 100 cases have been reported to date and the patient age ranges from $11-76$ years. ${ }^{13}$

Among mixed epithelial and mesenchymal tumours : adenosarcoma patients present at a mean age of 54 Years. ${ }^{13}$

Most patients of carcinosarcoma are older than 60 years and often have high-stage tumours at the time of diagnosis. Among sex cord-stromal tumours in pure stromal tumours fibroma, it may occur at any age, but is most frequent in middle age (average 48 years) and is less common before the age of 30 . Most thecomas (97\%) are unilateral and typically occur in postmenopausal women (mean 59 years); Leydig cell tumour occurs at an average age of 58 years and are commonly androgenic and only rarely oestrogenic. Germ cell tumours: dysgerminoma occurs almost exclusively in children and young women; the average patient age is 22 years. In 
squamous cell carcinoma the age distribution is wide, but most occur during the reproductive years and occur over a wide age range (19-87) years, average age is 55 year. ${ }^{13}$

\section{Conclusion:}

Most of the patients with malignant and benign ovarian tumours have presented in reproductive age adult women (20 - $49 \mathrm{yrs}$.); and some specific varieties of tumour (e.g. thecoma) presented the extremes of age.

There are variation in age of the patients of different kinds of the ovarian tumours in the region.

\section{Reference:}

1. Kumar, V., \& Robbins, S. L. 1. (2007). Robbins basic pathology (9th ed.).Chapter 22; The Female Genital Tract; 1022

2. IARC. Fact Sheets by Population - Globocan. Estimated incidence, mortality and 5-year prevalence: women. http://globocan.iarc.fr/ Pages/fact_sheets_population.aspx downloaded on 5.7.2017

3. Indian Council of Medical Research. Consolidated Report of Population Based Cancer Registries 2012-2014. National Cancer Registry Program Indian Council of Medical Research. Bangalore, 2006. http:// ncdirindia.org/NCRP/ALL_NCRP_REPORTS/ PBCR_REPORT_2012_2014/ALL_CONTENT/ Main.htm

4. Fritz A, Percy C, Jack A, Schanmugaratnam K, Sobin L, Parkin DM, Whelan S. International classification of diseases for Onchology, 3rd ed. World Health Organization. Geneva: Butler and Tanner, 2002

5. Malli M, Vyas B, Sunita Gupta S, Desai H. A histological study of ovarian tumors in different age groups Int J Med Sci Public Health. 2014; 3(3): 338-341 doi: 10.5455/ijmsph. 2013. 020120142
6. Nayak V, Sreelatha S, Vani B, Shobarani R. Clinicopathological Study of Ovarian Tumours. Journal of Evolution of Medical and Dental Sciences 2014; Vol. 3, Issue 53, October 16; Page: 12230-12233, DOI: 10.14260/jemds/ 2014/3616

7. Iyoke CA, Ugwu GO, Ezugwu EC, Onah N, Ugwu O, and Okafor O. Incidence, Pattern and Management of Ovarian Cancer at a Tertiary Medical Center in Enugu, South East Nigeria. Ann Med Health Sci Res. 2013 Jul-Sep; 3(3): 417-421. doi: 10.4103/2141-9248.117947

8. Gilani MM1, Behnamfar F, Zamani F, Zamani N. Frequency of different types of ovarian cancer in Vali-e-Asr Hospital (Tehran University of Medical Sciences) 2001-2003. Pak J Biol Sci. 2007 Sep 1;10(17):3026-8.

9. Thanikasalam K, Ho CM,. Adeeb N, Shahidan MN, Azizah WKN. Pattern of ovarian tumours among Malaysian women at General Hospital Kuala Lumpur. Med. J. Malaysia 1992; 47(2); 139-46.

10. Deeba F, Alam ABMM, Banu J. Clinlcopathological Study of Ovarian Cancer: A Multi Centered Study. J Shaheed Suhrawardy Med Coll, June 2013, Vol.5, No.13-6.

11. Okugawa K, Hirakawa T, Fukushima K, Kamura T, Amada S, Nakano H. Relationship between age, histological type, and size of ovarian tumors. Int J Gynaecol Obstet. 2001 Jul;74(1):45-50.

12. Jha, Karki. Histological pattern of ovarian tumors and their age distribution. Nepal Med Coll J. 2008 Jun;10(2):81-5.

13. Kurman RJ, Carcangiu ML, Herrington CS et al WHO Classification of Tumours of Female Reproductive Organs. In WHO Classification of Tumours. 4. Aufl. Lyon: WHO Press:2014: 8, $12-40$. 